\title{
Introduction: A Changing Indonesia
}

\author{
Maribeth Erb \\ National University of Singapore \\ Kathleen M. Adams \\ Loyola University Chicago, kadams@luc.edu
}

Follow this and additional works at: https://ecommons.luc.edu/anthropology_facpubs

Part of the Anthropology Commons

\section{Recommended Citation}

Erb, M. \& K. Adams. "Introduction: A Changing Indonesia." Southeast Asian Journal of Social Science (now known as Asian Journal of Social Science), 28(2): 1-9. Available at http://dx.doi.org/10.1163/ $030382400 \times 00028$

This Article is brought to you for free and open access by the Faculty Publications and Other Works by Department at Loyola eCommons. It has been accepted for inclusion in Anthropology: Faculty Publications and Other Works by an authorized administrator of Loyola eCommons. For more information, please contact ecommons@luc.edu. cC) (요요

This work is licensed under a Creative Commons Attribution-Noncommercial-No Derivative Works 3.0 License. (c) Brill, 2000. 


\section{Introduction: A Changing Indonesia}

\section{Maribeth Erb}

Department of Sociology

National University of Singapore

\author{
Kathleen M. Adams \\ Department of Sociology \& Anthropology \\ Soka University of America
}

\section{Dramas of Uncertainty}

It was a late afternoon in December 1998, on Kuta Beach, Bali, roughly six months after the abrupt end of an era in Indonesian history, the reign of President Suharto. An Indonesian man clad in black set down his black case, pulled out a loudspeaker and started beckoning passers-by to gather and witness his soon-to-begin display. His amplified voice boomed incessantly as he touted his credentials and expertise. As he spoke, he carefully marked off a six by six metre "stage" in such a way that viewers would not be able to see closely what was to transpire in the centre. He was an army man, he told us, and with his postings all over Indonesia he knew the dangers, particularly in this time of uncertainty. He had discovered in his travels a foolproof way of protecting himself. He then directed the spectators' attention to his assistant, a long-haired, emaciated individual, whom he introduced as a Dayak, well versed in the ancient Dayak arts of protection and defence. He boasted about his accomplice's astounding abilities. $\mathrm{He}$ could go into trance and swallow live snakes that would slither through his body; he could coax those same snakes through his nose and out his mouth. For the gathering crowd of curious passers-by listening to these amazing claims, it was at first unclear what this pair was selling. Eventually, however, it became apparent they were marketing magic stones, stones that originated from Kalimantan and were guaranteed to protect the owner in these times of uncertainty.

The seller soon unsheathed a machete knife. To demonstrate its sharpness, he waved the knife over his body, cutting hairs from his own head and arms, and then dramatically sliced the knife across his skin to draw blood. "If you carry one of these stones even a machete can not harm you", the seller proclaimed, and requested a volunteer from the audience. A man, apparently reluctantly, stepped forward. The seller presented him with a small pouch, which we were told held a magic stone. "Hold this.", he ordered and, before the man had a chance to demur, the seller thrust his machete into the crook of the man's arm, and pulled it out. No blood. "Do you want to buy one of these stones?" 
enquired the seller of his volunteer after this demonstration. Without speaking, the man nodded. Several thousand rupiah changed hands and the volunteer pocketed his treasure and quickly left the audience. Were there others who wanted to buy? One or two others hesitatingly showed interest. In the meantime, the Kalimantan Dayak was falling into a trance. Periodically redirecting our attention to the Dayak, the hawker enticed the small crowd with a description of what he was about to do. As he reminded us, this man could control snakes; we would witness a snake penetrate his nostrils and exit his mouth. The Dayak then produced what was declared to be a poisonous snake from his own black bag, which appeared to be writhing with snakes. After placing it on the ground, he slipped another black bag over his head and fell into trance.

Around the beach, night was approaching. Foreign tourists wandered over every now and then. They watched puzzled, uncertain what this show was about. Indeed why had these peddlers come to Kuta Beach, a famous tourist mecca, to sell their wares to an Indonesian audience, instead of finding a more locally-frequented spot? Observing this scene, the riddles that it invoked, it seemed perfectly consonant with what was unfolding on the wider Indonesian stage at that very moment. On both stages the slipperiness between the genuine and the contrived was palpable. In both arenas, confusion and suspicion reigned amongst the spectators. Watching the stone seller at work, it was hard to discern who in the audience was genuine, and who were stage props, planted to convince others to buy. It was difficult to fathom what was actually transpiring below the surface, what was real and what was pretence. Did outside observers necessarily understand less than those who listened and thought they understood? The man with the stone in his hand was cut by the knife, but did not bleed. Had he really been cut or was he part of the act? And there was the Dayak, lying on his back in "trance" with snakes emerging from his nose. Or were they? What was really going on under that black bag? The show seemed to be marketing the "primitive" and the "mystical". Was that the only power in which people could still believe, the only force that people trusted to protect them in these uncertain times?

The uncertainty of the performance, what was real, what was unreal, paralleled the events in Indonesia then, previously, and subsequently. Had, for example, the New Order really ended, or was Suharto still the puppeteer behind the screen? Who were the conjurers and perpetrators? Who were the genuine, innocent observers? Indeed, was, anyone innocent? Could in fact anyone watching be presumed to be innocent who stayed and supported, colluded with the performance? Could anyone be innocent who had watched and 
silently supported 32 years of corruption, murder, violence, and exploitation, be they the insiders, the "staged primitives", the audience, or the tourists? On the other hand, could anyone be presumed guilty either? (Heryanto, 1999).

We are left wondering at the present moment the extent to which these questions will ever be answered. The past three years have witnessed tremendous upsurge and ferment for change: the growing discontent; the events that led to President Suharto's fall after 32 years in power; the momentum that fuelled the first "free" election in decades; an historic referendum that ended Indonesian rule in East Timor and launched the embryonic beginning of a new nation state; the tremendous outpouring of feelings and ideas in the Press (which some now call the freest Press in Asia); and the energy that propelled the move towards reformasi. At the same time there have been moments of apathy and depression: Could things ever change? Will there be a backlash? A coup? A return to military rule? Will corruption end? Will the chains of patronage be swept away? Will the religious battles surging in the Moluccas, Lombok and elsewhere ever cease? Will there be an end to the terror and suppression of the ideals of various ethnic groups who yearn for autonomy, community participation, selfexpression, and freedom?

On the Eastern Indonesian island of Flores, in mid-1999, a number of people expressed opinions embodying the range of ideas about change that exist in Indonesia at the moment. One urban Flores woman who became very wealthy during Suharto's rule commented,

People in Indonesia just don't know how to say thank you. Here I am riding in a car, I have experienced flying in an airplane, all of these things because of the last government and the last president. We never had all this in the past. People just don't know how to say thank you.

As she stood by her car at a rural intersection voicing these sentiments, a villager bringing bananas from his field stopped by to listen to her words. He, however, had never been in an airplane, did not own a car, and perhaps had never been in one. The irony of that kind of scene, which represented the discrepancy of wealth and power that had developed in Flores and even more so in other areas in Indonesia over the past 30 years, had not been lost on other Florinese, who had energetically campaigned for "anything but Golkar" in the June elections. Another man with years of experience as a school teacher expressed a view increasingly being voiced across Indonesia: "We are going to have to rewrite our history. We never realized how much we had been duped." These comments, made to a senior seminary student 
who had been complaining about the conceited Javanese he had known in his seminary and about the Javacentricity of the nation, were part of a discussion of the suppression of "truth" during Suharto's reign. A freelance tourist guide and political activist for reformasi expressed an even more radical view: "Once people learn the truth of the New Order, 40 billion dollars stolen will mean nothing to them any more. One death sentence will not be enough to satisfy the people of Indonesia towards the ex-President." His words were prompted by a friend's disclosure of his horrific experiences as a nursing student in Eastern Flores in 1966, when he was responsible for burying the tortured bodies of those executed by the Indonesian army for alleged communist activity. But ironically, in the past June 1999 election, this man not only voted, but also campaigned, for Golkar.

These various views offer glimpses of "the people's" voice about the meaning of Indonesian political reform and the varied pathways to democracy. As these Florinese voices suggest, a range of views are found at all levels of the population, and are held by people for very different reasons. Not all of these are solely political, such as those analysed quite astutely by Arief Budiman (1999:44-50). Budiman's and several other papers in the volume Reformasi: Crisis and Change in Indonesia ${ }^{1}$ utilized Samuel Huntington's ideas on the possible pathways to democracy. Would the change be top-down (transformation), bottomup, from the grassroots (replacement), or gradual (transplacement) (see also van Klinken, 1999), or perhaps would no change take place at all? When Budiman and the others in that volume were writing, it was certainly more speculative than it is now, whether or not the impulses and forces towards reformasi would be able to continue unabated. At that time, as Hadiz's (1999) analysis in the Reformasi volume shows, there were still various obstacles strongly embedded in the legal and political framework. This was before some of the major electoral reforms described by Dwight King in this present volume had been defined.

The New Order government ruled for thirty-two years in what van Klinken characterizes very aptly as a "state of emergency" (1999:62), where danger was believed to be ever present and where it was suspected that the masses hid people who were potential enemies. The populace was presented as a source of latent chaos and anarchy. Certainly the past three years have seen a real state of emergency in Indonesia, where people plotted, violence emerged expectedly or unexpectedly in numerous places, and where no one could be sure who were friends or enemies. Is this emergency that emerged post-Suharto the chaos that the previous government warned would occur if tight reign were not kept on the country? Or, in fact, have things never really been as they seemed? Some of the papers in this volume quite forcefully 
prompt the reader to reflect precisely on this point. Space has been opened up for different people to define and contest the nature of the emergency, as well as the identities of the real villains, and to investigate what has actually been going on behind the screen all these years. This, we contend, is the real direction of change. We continue here the critical view of a number of key concepts used in the New Order, such as "development", "communism", and "nation", as analysed already by others such as Ariel Heryanto (1990; 1999), and Ben Anderson (1999). As implied by one of our Florinese friends above, reformasi entails a "rethinking" and "rewriting" of ideas and concepts of the past.

\section{Rewriting and Re-Righting History and Politics}

As the articles in this special issue illustrate, ongoing struggles over competing images of the past, present, and future are rampant in Indonesia and encroach on all areas of life, from conceptions of proper labour relations, to the construction and meaning of history, to debates about development, religion, and political governance. Taken together, several of the articles in this volume convey the sense that the dramatic changes in Indonesia over the past three years have made this a fertile time for reassessing, rewriting, and correcting Indonesian historical and political records. Budiawan, for instance, discusses how recently-released political prisoners have turned to inscribing their memories of suffering, striving to re-right history by rewriting it to reflect their experience as "victims" rather than as "perpetrators" in the "September 30, 1965 affair" (which involved the kidnapping and slaying of six high-ranking Indonesian army officers by a regiment of Presidential guards and prompted Suharto's rise to power). As Budiawan illustrates, certain Muslim groups take issue with these counter-narratives and now struggle to reaffirm the official history, which is more in accordance with their own memories and intrinsic to constructions of their own identities. Which set of memories will prevail and become enshrined as "history" remains to be seen, as the struggle to write/right the past continues.

Likewise, the Balinese political cartoons examined by Richard Ostrom can be seen as instruments for challenging the classic New Order representations of tourism development as universally beneficial for Balinese. As Ostrom's article illustrates, Benedict Anderson's observations concerning the role of Indonesian cartoons in the early 1970 s are equally apt in these times of change. Cartoons continue to be "a way of creating collective consciences by people without access to 
bureaucratic or other institutionalized forms of political muscle" (Anderson, 1990 [1973]:163). The contemporary Balinese political cartoons analysed by Ostrom lend voice to those disenfranchised by tourism development projects on the island. As the cartoons depict with biting humour, tourism has brought with it the alienation of Balinese from their lands, prostitution, and the siphoning of profits by Javanese and Western investors. These cartoons, then, both rewrite and "right" the Suharto-era narrative of Bali as Indonesia's gleaming model of unproblematic development via tourism promotion.

Vedi Hadiz's article also addresses the theme of rewriting the past, albeit in a slightly different manner. As Hadiz ultimately suggests in his insightful examination of political change in Indonesia, current Indonesian political battles centre on elites striving to reconfigure themselves in the new era as "middle class reformers" with varying degrees of distance from the New Order. Here it is a rewriting of past identities and past affiliations that is at issue. From this perspective, Hadiz's analysis suggests some serious constraints on reformasi, despite what seems to be a decline in political repression. As he observes, the opportunities presented by reformasi are not fully exploitable by all civil society groups, as Indonesia's sociopolitical framework is currently being reshaped via negotiations between party elites (and the military) "largely draw [n] from the middle layers of the New Order's former network of patronage". In a sense, present-day reformasi politics, then, may well be more of a reframing of the past than a fundamental break with the past.

Finally, in her discussion of labour relations in the Habibie Interregnum, Michele Ford highlights the New Order's construction of communism as the most salient of evils and its elevation of Pancasila (the right to religious belief, humanitarianism, unity of the nation, democracy, social justice) to almost sacred status. Her article traces the taming of the social justice dimension of Pancasila under the discourse of development during the Suharto era. As she implies, a different sort of political rewriting was transpiring in this period, one designed to inhibit ordinary people from organizing or challenging government directives by drawing on a reconfigured concept of Pancasila. In essence, the New Order's celebrated principle of Pancasila was transformed into a potent rhetoric for co-opting labour and for justifying the involvement of the military in industrial relations when labour could not be co-opted. In this respect, as Michele Ford shows, Pancasila was reconfigured and drawn upon as a tool of repression, instead of, as it was originally intended, as a guarantor of rights and freedom. Although Ford concentrates on the government's rewriting of the concept of Pancasila, the manipulation and reconfiguring of this concept was not 
unidirectional. In the late 1980s and early 1990s, hinterland villagers in the Toraja highlands of Sulawesi and in Nusa Tenggara Timur province were co-opting the concept for their own ends, in some cases to resist restrictions imposed by the national government. ${ }^{2}$

Taken together, then, these papers by Budiawan, Ostrom, Hadiz and Ford illustrate the struggle to redefine concepts from the past in the present, be they concepts that were taken as essentially sacred, or as essentially demonic. Hence, despite the cautious suggestions of change indicated by these authors, even as they wonder how far change has really progressed, these pieces do illustrate a rather important beginning of an ideological revolution, a sweeping away of the Suhartoera perversion of language and ideas.

Dwight King's article offers us more concrete examples of actual changes implemented in 1998 and 1999. These electoral reforms described by King allowed national elections to take place in June 1999 that ultimately installed what appears to be a radically different government. Illustrated here is the tremendous amount of negotiation, and arm twisting, capitulation and hardheadedness that resulted in the implementation of these reforms.

Finally, Maribeth Erb's paper offers an illustration of how variable the crisis has been in different regions and even within the same region. Her study of the diversity even within two towns in Flores spotlights a part of Indonesia that is seldom the focus of media attention. Even within one regency, people who have developed different ways of economic livelihood and different political concerns have experienced the uncertainties of the past three years in very different ways. This paper also draws attention to a comparative element. How far can understanding globalizing trends of nation-building and industrialization, and consumerism help us to get an insight into the diversity of responses in each local situation? This view from the hinterlands also reminds us that while much of the political and economic policy-making is still centred on Java, we need to deepen our understanding of the ways in which the events of the past three years have varying ramifications and meanings in other regions of Indonesia.

\section{Closing Reflections}

In a recent work, Benedict Anderson (1998) invoked Jose Rizal's notion of spectres of comparison (el demonio de las comparaiones) to convey the idea of a kind of incurable double vision, the experience of being unable to see things "matter-of-factly" but rather simultaneously from multiple perspectives, with multiple referents. In a sense, this notion of spectres 
of comparison is apt for this volume's theme of a changing Indonesia. As with the magic-stone spectators in the opening vignette who were both drawn into the mystic narrative of age-old protective powers and simultaneously distrusting cynics, so too are today's observers of the ongoing transformations of Indonesia. On the one hand, imagining true reformasi as a viable possibility and, on the other hand, succumbing to scepticism about the challenges to real change, the contributors to this volume offer multiple perspectives and multiple lenses on an Indonesia in flux. We are sceptical and yet, as cautious observers, we want to believe that the "magic stones" of "democracy", "transformation" and "reformasi" will work. That is, we hope that these and other "magic stones" will protect Indonesians from one another and at the same time shield Indonesia from the destructive dimensions of the wider globalizing twenty-first century world.

\section{Acknowledgements}

A number of the papers in this volume were originally presented at the Fifth ASEAN Seminars for Social Development at the Prince of Songkhala University in Pattani, Thailand. The authors want to express gratitude to the National University of Singapore and the Frederich Neumann Foundation for support for that conference. Kathleen Adams would like to thank the Centre for Advanced Studies at the National University of Singapore for the Isaac Menasseh Meyer Fellowship that made it possible for her to visit Singapore for two months, from July-September 1999. Ryan Bishop and Kay Mohlman were particularly congenial colleagues at that time, and Kathleen would like to express her gratitude to them. It was during those months that we came up with the idea for this special issue. Many people initially showed enthusiasm towards the idea of this issue, and although for various reasons they could not contribute articles, the authors would like to thank Aris Ananta, Nancy Lutz, Muchtar Ahmad, Prijono Tjiptoherijanto, Carole Faucher, Filomeno Aquilar and Edward Aspinall for their support. We would also like to thank Vedi Hadiz, Daniel Lev, and Carole Faucher for reading various papers included here, and offering their valuable time to give advice on this issue.

\section{Notes}

1. This volume was the product of a conference in December 1998 at Monash University.

2. For instance, one of the co-editors was urged to teach English for pay in a remote Sulawesi village and when she demurred noting that her research visa did not permit her to work, her would-be Indonesian employer declared that teaching English was in keeping with Pancasila and would be applauded by the government. 


\section{References}

Anderson, Benedict R.O.G.

1990 "Cartoons and Monuments: The Evolution of Political Communication Under the New Order". In Benedict R.O.G. Anderson, Language and Power: Exploring Political Cultures in Indonesia. Ithaca: Cornell University Press, pp. 152-93.

1998 Spectres of Comparison: Nationalism, Southeast Asia and the World. London and New York: Verso.

1999 "Indonesian Nationalism Today and in the Future". Indonesia, 67:111.

Budiman, Arief

1999 "The 1998 Crisis: Change and continuity in Indonesia". In Arief Budiman, Barbara Hatley and Damien Kingsbury (eds.), Reformasi:

Hadiz, Vedi

Crisis and Change in Indonesia. Melbourne: Monash Asia Institute.

1999

"Contesting Political Change after Suharto". In Arief Budiman, Barbara Hatley and Damien Kingsbury (eds.), Reformasi: Crisis and Heryanto, Ariel

Change in Indonesia. Melbourne: Monash Asia Institute.

1990 "The Making of Language: Developmentalism in Indonesia". Prisma: The Indonesian Indicator, 50:40-53.

1999 "Where Communism Never Dies: Violence, Trauma and Narration in the Last Cold War Capitalist Authoritarian State". International Journal of Cultural Studies, 2 (2):147-77.

van Klinken, Gerry

1999 "How a Democratic Deal Might be Struck". In Arief Budiman, Barbara Hatley and Damien Kingsbury (eds.), Reformasi: Crisis and Change in Indonesia. Melbourne: Monash Asia Institute. 